\title{
Carbon regeneration in the Cariaco Basin, Venezuela
}

\author{
Arístides Marquez ${ }^{1}$,Andrew Dale ${ }^{2}$, Luis Troccoli Ghinaglia ${ }^{3}$, Fabiola López Monroy4, \\ William Senior ${ }^{1}$, Aida Ríos ${ }^{5}$, Frank Muller Karger ${ }^{6}$, Yrene Astor ${ }^{7}$, Ramón Varela $^{7}$
}

\author{
${ }^{1}$ Instituto Oceanográfico de Venezuela, Universidad de Oriente. \\ (Av. Universidad. Cumaná. Venezuela) \\ ${ }^{2}$ GEOMAR | Helmholtz Centre for Ocean Research Kiel \\ (Wischhofstrasse 1-3, 24148 Kiel, Germany) \\ ${ }^{3}$ Universidad de Oriente. Instituto de Investigaciones Científicas. \\ (Boca de Río, Isla de Margarita, Venezuela) \\ ${ }^{4}$ Universidad de Oriente. Escuela de Ciencias Aplicadas del Mar. \\ (Boca de Río, Isla de Margarita, Venezuela) \\ ${ }^{5}$ Vigo Marine Research Institute (CSIC). \\ (Eduardo Cabello, 6.36208-Vigo, Spain) \\ ${ }^{6}$ University of South Florida, College of Marine Science. \\ (St. Petersburg, FL 33701, United States Beach Dr. Apt. 1601, St. Petersburg, FL 33701, United States) \\ ${ }^{7}$ EDIMAR-FLASA \\ (Punta de Piedras, Apt. 144, Nueva Esparta, Venezuela) \\ *Corresponding author: luis.troccoli@gmail.com
}

\section{Abstract}

The carbon regeneration in the water column of the Cariaco Basin (Venezuela) was investigated using a regression model of total alkalinity (TA) and the concentration of total inorganic carbon $\left(\mathrm{TCO}_{2}\right)$. Primary productivity (PP) was determined from the inorganic carbon fraction assimilated by phytoplankton and the variation of the 22 and $23^{\circ} \mathrm{C}$ isotherm was used as an indicator of coastal upwelling. The results indicate that $\mathrm{CO}_{2}$ levels were lowest $(1962 \mu \mathrm{mol} / \mathrm{kg})$ at the surface and increased to $2451 \mu \mathrm{mol} / \mathrm{kg}$ below the oxic-anoxic redox interface. The vertical regeneration distribution of carbon was dominated ( $82 \%)$ by organic carbon originating from the soft tissue of photosynthetic organisms, whereas $18 \%$ originated from the dissolution of biogenic calcite. The regeneration of organic carbon was highest in the surface layer in agreement with the primary productivity values. However, at the oxic-anoxic interface a second more intense maximum was detected (70-80\%), generated by chemotrophic respiration of organic material by microorganisms. The percentages in the anoxic layers were lower than in the oxic zone because aerobic decomposition occurs more rapidly than anaerobic respiration of organic material because more labile fractions of organic carbon have already been mineralized in the upper layers.

Descriptors: Cariaco Basin, Carbon regeneration, Water column, Coastal upwelling.

\section{RESUMO}

A regeneração de carbono na coluna de água da $\mathrm{Ba}-$ cia de Cariaco (Venezuela) foi investigada utilizando um modelo de regressão de alcalinidade total (TA) e a concentração de carbono inorgânico total $\left(\mathrm{TCO}_{2}\right)$. Produtividade primária (PP) foi determinada a partir da fracção de carbono inorgânico assimilável pelo fitoplâncton e a variação da isotérmica de 22 e $23^{\circ} \mathrm{C}$ foi utilizada como um indicador de ressurgência costeira. Os resultados indicam que os níveis de $\mathrm{CO}_{2}$ eram os mais baixos $(1962 \mu \mathrm{mol} / \mathrm{kg})$ na superfície e aumentado para $2451 \mu \mathrm{mol} / \mathrm{kg}$ redox abaixo da interface ico-anóxica. A distribuição vertical de regeneração de carbono foi dominada (82\%) por carbono orgânico originário do tecido mole de organismos fotossintéticos, enquanto $18 \%$ foram originados da dissolução de calcite biogênica. A regeneração do carbono orgânico foi maior na camada superficial de acordo com os valores de produtividade primária. No entanto, na interface ico-anóxica foi detectado um segundo máximo mais intenso (70-80\%), gerado pela respiração quimiotrófica de material orgânico por microrganismos. As percentagens nas camadas anóxicas foram menores porque a decomposição aeróbica ocorre mais rapidamente do que a respiração anaeróbica de matérias orgânicas, pois as fracções mais lábeis de carbono orgânico já foram mineralizadas nas camadas superiores.

Descritores: Bacia de Cariaco, Regeneração de carbono, Coluna de água, Afloramento costeiro. 


\section{INTRODUCTION}

Oceans play a central role in modulating climate through the absorption and exchange of carbon dioxide from the atmosphere and its sequestration into the oceans' interior. At the same time, the mechanisms of exchange and assimilation of heat make the oceans important reservoirs of $\mathrm{CO}_{2}$ that can influence climatic changes (STEINBERG et al., 2001; SITCH et al., 2015; MCKINLEY et al., 2016). The magnitude of the oceanic $\mathrm{CO}_{2}$ sink is influenced by the biological pump, that is, the sequestration of atmospheric $\mathrm{CO}_{2}$ by phytoplankton during primary production and the subsequent export by the sinking of particulates out of the mixed layer. Only a fraction of the sinking particles reach the sea floor; $\sim 1 \%$ of organic carbon that sinks out of the surface mixed layer reaches the sediment (BERGER et al., 1988; THUNELL et al., 2000; SMOAK et al., 2004; THUNELL et al., 2007).

The continental margins are sites of active physical and biogeochemical processes that are relevant to the global carbon cycle (LIU et al., 2000; ASTOR et al., 2003; ASTOR et al., 2013; BAUER et al., 2013). These include regions of coastal upwelling where intermediate and deep water masses rise to the surface, degas, and generate a flux of $\mathrm{CO}_{2}$ into the atmosphere (SMITH, 1994; COBOVIVEIROS et al., 2013). In addition, limiting nutrients for the biota are transported by the upwelling waters to the surface layers and help sustain primary productivity (HUTCHINGS et al., 1994; IANSON, 2003; CAPONE; HUTCHINS, 2013; SCRANTON et al.; 2014). The transport of biological material to the ocean's interior is the main driver of the non-zero gradient of many dissolved species in seawater and an important regulator of atmospheric $\mathrm{CO}_{2}$ on millennial timescales (LOUANCHI; NAJJAR, 2000; SIPPO et al.; 2016). In the open ocean, the fluxes of carbon through the water column decease exponentially with water depth due to aerobic respiration by microorganisms (PACE et al., 1987; PACKARD et al., 2015).

Atmospheric carbon dioxide $\left(\mathrm{CO}_{2}\right)$ has increased from 278 to 400 parts per million (ppm) over the industrial period and, together with the increase of other greenhouse gases, has driven a series of major environmental changes (GATTUSO et al., 2015). Approximately $30 \%$ of the anthropogenic carbon emitted from fossil fuels is removed from the atmosphere by the ocean, which may lead to an uncertain future for the planet's climate (OCCC, 2004; JOHN et al., 2007). Biogeochemical ocean circulation models suggest that the ocean absorbed approximately $37 \mathrm{Pg} \mathrm{C}$ of anthropogenic C between 1994 and 2010, increasing the inventory from $118 \pm 20 \mathrm{Pg} \mathrm{C}$ to $155 \pm 31$ $\mathrm{Pg} \mathrm{C}$. This is equivalent to a mean annual uptake rate of approximately $2.3 \mathrm{Pg} \mathrm{C}$ year, or approximately $27 \%$ of the total anthropogenic $\mathrm{C}$ emissions over this time period (KHATIWALA et al., 2013).

The present investigation was carried out within the framework of the Cariaco Time-Series Program (Carbon Retention in a Colored Ocean) with the objective of estimating the percentages of organic and inorganic regenerated carbon in the Cariaco Basin.

\section{MATERIAL AND METHODS}

\section{STUDY AREA}

The Cariaco Basin (Figure 1) is the largest anoxic and truly marine pelagic system (MADRID et al., 2001). It forms a depression ca. $160 \mathrm{~km}$ long and $70 \mathrm{~km}$ wide on the Venezuelan continental shelf with an approximate maximum water depth of $1400 \mathrm{~m}$ (MULLER-KARGER et al., 2001; ASTOR et al., 2013). A pronounced seasonality can be observed in water column physical parameters at the start of the year caused by the seasonal displacement of the Inter-Tropical Convergence Zone (ITCZ) that generates significant variability in wind regime, currents and river discharge (RICHARDS, 1960; HERRERA; FEBRES ORTEGA, 1975; MULLER-KARGER; APARICIO, 1994; ASTOR et al., 1998; RUEDA-ROA; MULLER-KARGER, 2013). These changes lead to an increase in primary production that exceeds $500 \mathrm{gCm}$ ${ }^{2} \mathrm{yr}^{-1}$ (MULLER-KARGER et al., 2001). The surface water layers within the basin also experience a decrease in temperature, mainly due to the influence of coastal upwelling (MULLER-KARGER et al., 2001). Below 200 $\mathrm{m}$, the water mass is isolated and is characterized by nearconstant temperature, salinity and total anoxia (ASTOR et al., 1998; SCRANTON et al., 2002, ASTOR et al., 2013). Due to the geomorphology of the basin, advection is confined to the surface layers of the water column, from which biogenic material and detritus rich in opal, organic carbon and lithogenic material are exported to the deeper waters (THUNELL et al., 2000; MULLER-KARGER et al., 2001). The laminated sediments underlying the anoxic water mass serve as an important repository for past variability of inter- and extra-tropical climate (REUER et al., 2003; MULLER-KARGER et al., 2001; SCRANTON et al., 2014). 


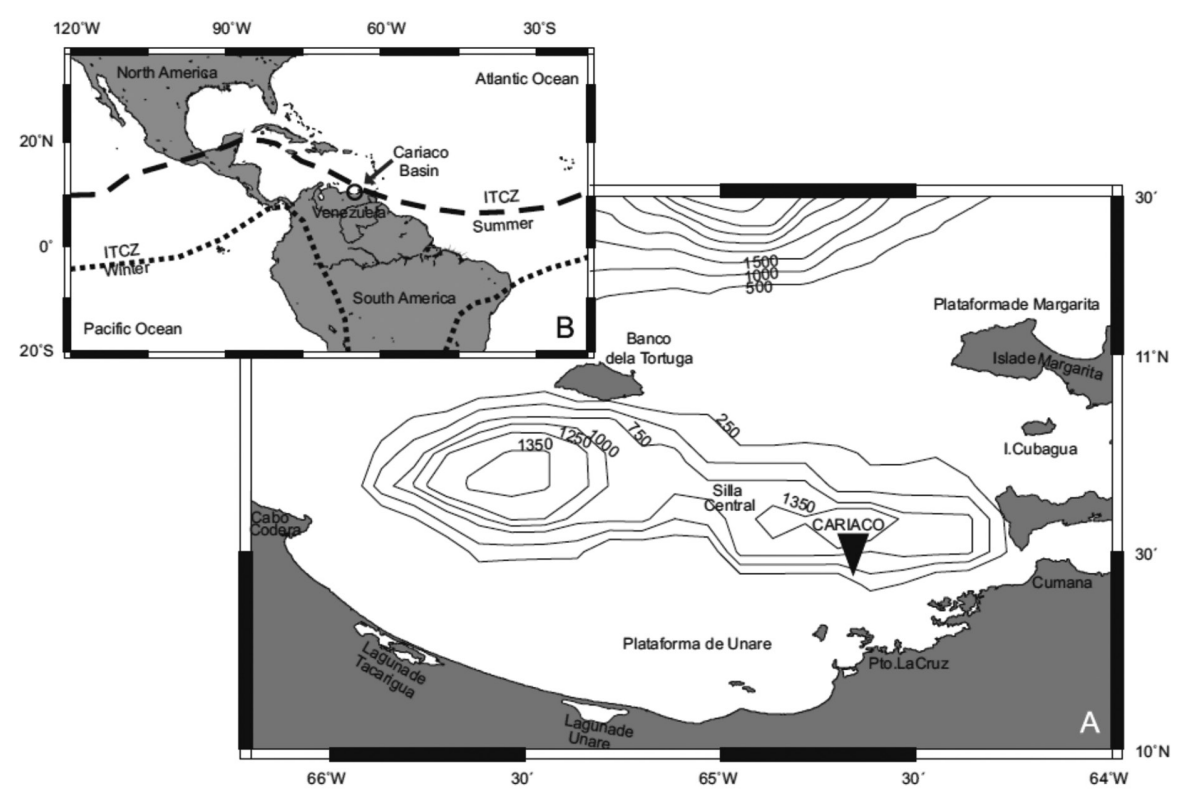

Figure 1. Northeastern Venezuela showing the Cariaco Basin. The sampling station (CARIACO) is indicated $\left(10^{\circ} 30^{\prime} \mathrm{N}, 64^{\circ} 40^{\prime} \mathrm{W}\right)$.

The data presented in this study originate from samples that were collected monthly from January 2006 to September 2007 at the Cariaco sampling station (Figure 1) at 18 water depths from the surface down to $1310 \mathrm{~m}(1$, $7,15,25,35,55,75,100,130,160,200,250,300,350$, $400,500,750,1310 \mathrm{~m})$. Water samples were recovered with a CTD (SBE 25) rosette equipped with 12 Niskin bottles $(8 \mathrm{~L})$ and dissolved oxygen, fluorescence and light attenuation sensors. The upper layers of the basin present the most pronounced changes in temperature due to the influence of coastal upwelling and lateral advection of cooler water masses from the Caribbean Sea (ASTOR et al., 1998; MULLER-KARGER et al., 2001; ASTOR et al., 2003). Vertical mixing below $100 \mathrm{~m}$ is inhibited by the presence of a strong pycnocline (SCRANTON et al., 1987; SCRANTON et al., 2014). Temperatures were only used down to 200 meters. Below $200 \mathrm{~m}$, the waters are isolated and acquire anoxic characteristics with almost constant temperature and salinity (ASTOR et al., 1998; ASTOR et al., 2013; SCRANTON et al., 2014). Primary productivity (PP) was determined from the inorganic carbon fraction assimilated by phytoplankton using ${ }^{14} \mathrm{C}$ bicarbonate following the method of STEEMAN-NIELSEN (1952) with modifications by KNAP et al. (1997) and UNESCO (1994). The procedure is derived from that employed in BATS (Bermuda Atlantic Time-series Study, KNAP et al., 1997) adjusted for the elevated productivity of the sampling station. The minimum incubation time of the samples was between 4 and $5 \mathrm{~h}$, which detects $\mathrm{C}$ fixation rates of 0.05 to $100 \mathrm{mg} \mathrm{C} \mathrm{m}^{-3} \mathrm{~h}^{-1}$. Analysis of total alkalinity (TA) was performed following BRELAND and BYRNE (1993). Certified reference materials (supplied by A. Dickson) were used. Water samples for the determination of TA were siphoned from the Niskin bottles into dark 250 $\mathrm{ml}$ borosilicate containers and fixed with $50 \mathrm{ml}$ saturated $\mathrm{HgCl}_{2}$ (equivalent to $50 \mu \mathrm{M} \mathrm{Hg}$ ). The samples were stored at $4{ }^{\circ} \mathrm{C}$ until analysis. In the laboratory, samples were acidified by titration to the inflexion point using bromocresol indicator. TA concentrations were calculated using absorbance readings at $444 \mathrm{~nm}$ and $616 \mathrm{~nm}$, with a precision of $\pm 4 \mu \mathrm{mol} \mathrm{kg}^{-1}$. Samples for the determination of $\mathrm{pH}$ were taken directly from the Niskin bottles and measured within $1 \mathrm{~h}$ by spectrophotometry (Ocean Optics SD-1000) using $10 \mathrm{~cm}$ cells (CLAYTON; BYRNE, 1993; DICKSON; GOYET, 1994). The procedure measures the absorbance at $434 \mathrm{~nm}$ and $578 \mathrm{~nm}$ before and after the addition of the purple indicator $\mathrm{m}$-cresol. The cells were placed in a water bath at $25{ }^{\circ} \mathrm{C}$ for 15 minutes prior to measurement. This methodology is used for the CARIACO time-series project and more details are given in ASTOR et al. (2005). The precision was $\pm 0.003 \mathrm{pH}$ units.

$\mathrm{TCO}_{2}$ concentrations were calculated using the program CO2SYS (LEWIS; WALLACE, 1995) from $\mathrm{pH}$ and TA using the equilibrium constants of MERHBACH et al. (1973) and MILLERO (1995). This program allows the components of the carbon dioxide system to be 
determined using two variables only. The precision of this approach was $5.6 \mu \mathrm{mol} / \mathrm{kg}$ (ASTOR et al., 2005; ASTOR et al., 2013).

The regeneration of carbon in the water column was calculated from TA and $\mathrm{TCO}_{2}$ using equations (1) and (2) in BROECKER and PENG (1982). This method calculates the levels of organic and inorganic carbon regenerated in the water column from the slope of the TA vs $\mathrm{TCO}_{2}$ regression where $\mathrm{TCO}_{2}=\sum \mathrm{CO}_{2}$. The model considers that, in the case of dissolution of calcareous skeletons $\left(\mathrm{CaCO}_{3}\right)$, TA increases twice as much as $\sum \mathrm{CO}_{2}$. Similarly, when biogenic tissue is mineralized, TA decreases by one unit for each mole of nitrate formed by the nitrification of organic nitrogen with a corresponding increase in $\sum_{2} \mathrm{CO}_{2}$ set by the C:N ratio of the organic material (RÍOS et al., 1989). Based on equations used by (BROECKER; PENG,1982) on inorganic carbon derived from calcareous test and organic carbon from soft tissue (REDFIELD, 1963), is the slope of the TA vs $\mathrm{TCO}_{2}$ relationship (RÍOS et al., 1995).

$\frac{\Delta \mathrm{TA}}{\Delta \Sigma \mathrm{CO}_{2}}=\frac{2 \Delta \mathrm{C}_{\mathrm{CaCO} 3}}{\Delta \mathrm{C}_{\mathrm{CaCO} 3}+\Delta \mathrm{C}_{C o r g}}-\frac{\Delta \mathrm{C}_{C o r g}}{\mathrm{R}\left(\Delta \mathrm{C}_{\mathrm{CaCO} 3}+\Delta \mathrm{C}_{\mathrm{Corg}}\right)}$

$$
\frac{\Delta \mathrm{C}_{\mathrm{CaCO} 3}}{\Delta \mathrm{C}_{\text {Corg }}}=0.5\left(\frac{\Delta \mathrm{TA}}{\Delta \Sigma \mathrm{CO}_{2}}+\frac{1}{\mathrm{R}}\right)-\frac{\Delta \mathrm{TA}}{\Delta \Sigma \mathrm{CO}_{2}}
$$

The percentage of organic and inorganic carbon was determined for each month in order to investigate possible seasonal changes in the regeneration of carbon in the regression model. Monthly profiles of TA and $\mathrm{TCO}_{2}$ were regressed to obtain the slope. Thus, all the TA and $\mathrm{TCO}_{2}$ were averaged at each depth and used in the regression model.

To validate the data and determine if monthly and annual variations existed in the percentages of regenerated carbon, multifactor ANOVA (analysis of variance type III) was used at a significance level of 5\%. Homogeneity of variance was checked using the Cochran test for 18 months and 306 observations. To identify the homogeneous groups in the analysis, the multiple range LSD test was used at a level of 5\% (SOKAL; ROHLF, 1969, JOHNSON; WICHERN, 1992). The ANOVA analysis was made using the statistical package Statgraphics plus 5.1.

\section{RESULTS}

Primary production in the Cariaco Basin presented strong seasonality, with higher rates during the upwelling season that occurs from November until April (Figure 2). At this time, water ascends to the surface from $\sim 100-120$ $\mathrm{m}$ depth and is relatively cool $\left(22\right.$ to $23^{\circ} \mathrm{C}$; Figure 3$)$ and enriched in nutrients (ASTOR et al., 1998; MULLERKARGER et al., 2001; ASTOR et al., 2003; SCRANTON et al., 2014). Despite the high productivity, $\mathrm{TCO}_{2}$ concentrations were relatively low in the photic zone $(<200$ $\mathrm{m})$, with values between 1968 and $2300 \mu \mathrm{mol} \mathrm{kg} \mathrm{kg}^{-1}$. Below the anoxic chemocline $(>250 \mathrm{~m}), \mathrm{TCO}_{2}$ concentrations

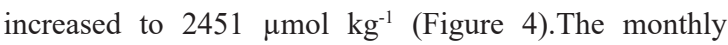
and annual percentages of organic and inorganic carbon regenerated in the Cariaco Basin showed no significant seasonal differences at a significance level of $p<0.05$. The $p$-values test the statistical significance of each of the factors. Since no $p$-values were less than 0.05 , none of the factors had a statistically significant effect on organic and inorganic carbonic at the $95 \%$ confidence level. The mean percentages of inorganic and organic carbon over the study period were $24 \%$ and $76 \%$, respectively (Figure 5).

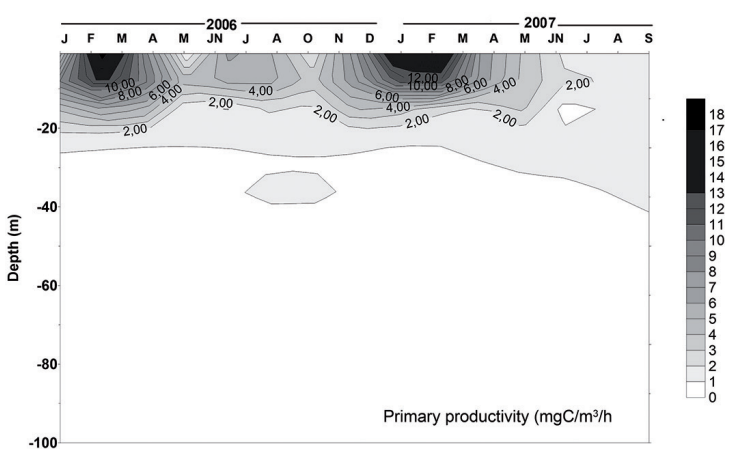

Figure 2. Distribution of primary productivity ( $\mathrm{mg} \mathrm{C} \mathrm{m-3} \mathrm{h-1)} \mathrm{at} \mathrm{the}$ sampling station in Cariaco Basin from January 2006 to September 2007.

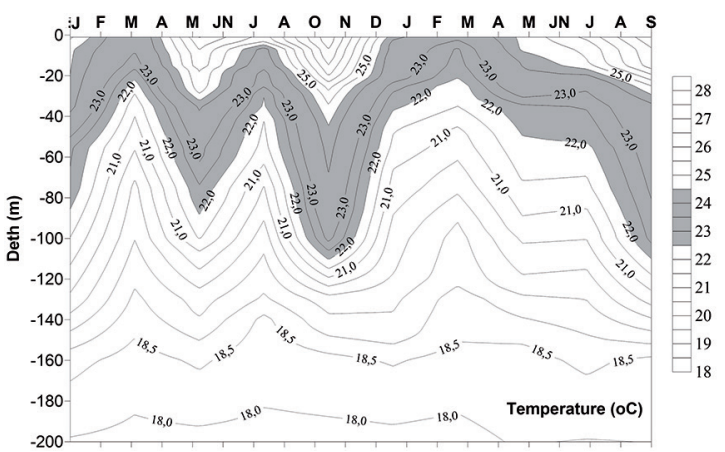

Figure 3. Distribution of temperature $\left({ }^{\circ} \mathrm{C}\right)$ at the sampling station in Cariaco Basin from January 2006 to September 2007. Gray contours show the variability in the $23^{\circ} \mathrm{C}$ isotherm during coastal upwelling.

\section{DISCUSSION}

Coastal upwelling systems account for approximately half of the global ocean's primary production and 


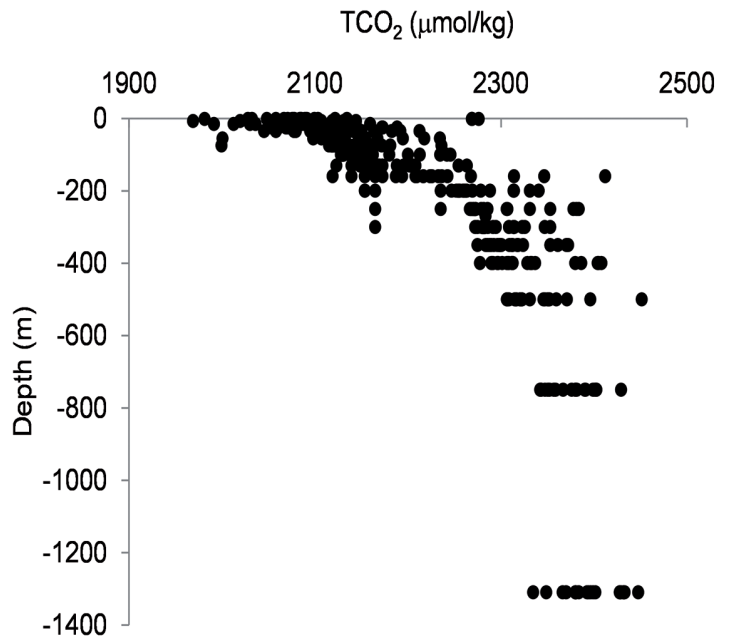

Figure 4. Distribution of $\mathrm{TCO}_{2}(\mu \mathrm{mol} / \mathrm{kg})$ at the sampling station in Cariaco Basin from January 2006 to September 2007.

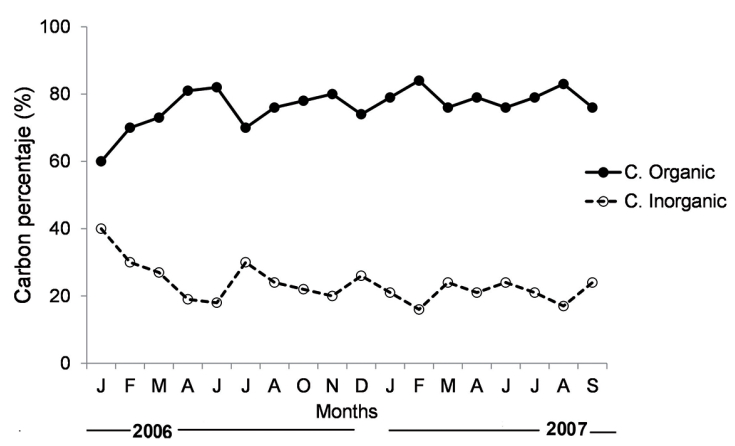

Figure 5. Monthly percentages of depth-integrated regenerated carbon (inorganic and organic) at the sampling station in Cariaco Basin from January 2006 to September 2007.

contribute disproportionately to biologically driven carbon sequestration (ABRANTES et al., 2016). Diatoms, silica-precipitating microalgae, constitute the dominant phytoplankton in these productive regions, and their abundance and assemblage composition in the sedimentary record is considered one of the best proxies for primary productivity (ABRANTES et al., 2016). In the Cariaco Basin primary production is dominated by diatoms (THUNELL et al., 2000; ROMERO et al., 2009) and is mainly confined to the upper $50 \mathrm{~m}$ of the water column (Figure 2). Production is relatively higher in the upper $7 \mathrm{~m}$, with values exceeding $4 \mathrm{mg} \mathrm{C} \mathrm{m}^{-3} \mathrm{~h}^{-1}$. However, levels of $1 \mathrm{mg} \mathrm{C} \mathrm{m}^{-3} \mathrm{~h}^{-1}$ were detected between 25 and 50 $\mathrm{m}$ throughout the study period. The highest rates measured in this study were $17 \mathrm{mg} \mathrm{C} \mathrm{m}^{-3} \mathrm{~h}^{-1}$ between January and March. An interesting finding was that in non-upwelling months, for example July 2002, uncharacteristically high values $\left(5 \mathrm{mg} \mathrm{C} \mathrm{m}^{-3} \mathrm{~h}^{-1}\right)$ were measured. These values are influenced by a secondary upwelling caused by the regional geostrophic flow FEBRES-ORTEGA; HERRERA, 1975; HERRERA; FEBRES-ORTEGA, 1975; MULLERKARGER et al., 2001; LORENZONI et al., 2013). The high productivity is reflected in the annually integrated values which exceed $600 \mathrm{~g} \mathrm{C} \mathrm{m}^{-3} \mathrm{~h}^{-1}$. These agree with the rates of 540 to $690 \mathrm{~g} \mathrm{C} \mathrm{m}^{-3} \mathrm{~h}^{-1}$ reported by MULLERKARGER et al. (2001). MULLER-KARGER et al. (2001) and ASTOR et al. (2003) further indicate that, besides upwelling, ventilation processes in this zone also induce an increase in productivity. Temporal variability in the production and export of diatoms in the Cariaco Basin is primarily controlled by the seasonal cycle of primary production in the surface waters. When the ITCZ reaches its southernmost position during the boreal winter, strong E-NE trade winds enhance the upwelling of nutrients into surface waters, which in turn results in increased fluxes of diatoms and bulk biogenic components to the seafloor. The ITCZ moves northward in the boreal summer, resulting in weakened E-NE trades (ASTOR et al., 2003), decreased input of nutrients to the surface water and reduced primary production. Diatom and opal fluxes reach their lowest values during boreal summers off Venezuela (ROMERO et al., 2009).

The regeneration of the monthly organic carbon fraction varied between 60 and 82\% (Figure 5), between January and June 2006 and then decreased to $68 \%$ in July 2006. Thereafter, the variability was low and was maintained between $70 \%$ and $83 \%$ during the following months. The variation oscillated between $18 \%$ and $40 \%$ for inorganic carbon, with decreases from $40 \%$ to $18 \%$ from January to June 2006 and a secondary maximum of $32 \%$ in July 2006 . The decrease in the percentage of regenerated organic carbon, although lower in the first months of the year -particularly in 2006, coincides with upwelling intensity, which was less intense in 2006 than 2007 (Figure 3). In July 2006, the decrease was lower than in July 2007 due to a stronger increase of the 23 ${ }^{\circ} \mathrm{C}$ isothermal. FEBRES-ORTEGA (1974) indicated that the geostrophic flow in the Cariaco Basin has a notable influence in the upwelling of cold water to the surface. The upwelling events are characteristic of the central and eastern coast of Venezuela, originating when the Trade winds blow from NE-E-SE to NW-W-SW (MULLERKARGER; APARICIO, 1994; ASTOR et al., 1998; ASTOR et al., 2003; ALVERA-AZCARATE et al., 2009; RUEDA-ROA; MULLER- KARGUER, 2014). However, lateral advection also has an influence, transporting water 
masses from the regions of greatest upwelling, such as the north coast of Sucre State (FEBRES-ORTEGA, 1974; RUEDA-ROA; MULLER-KARGUER, 2014). The regeneration of organic carbon is a source of marine dissolved organic matter (DOM), which is one of the largest reservoirs of reduced carbon in the ocean. Thus small changes in the cycling of DOM can have dramatic impacts on the magnitude of $\mathrm{CO}_{2}$ released or sequestered by marine systems ( 662 Pmol C) (HANSELL et al., 2009; LORENZONI et al., 2013).

The slope of the regression curve of the TA vs $\mathrm{TCO}_{2}$ (Eq. 2) was 0.22 (Figure 6). Accordingly, when the variation of organic carbon produced by the decomposition of soft tissue $\left(\Delta \mathrm{C}_{\text {org }}\right)$ is equal to 1 , the variation of inorganic carbon generated by the dissolution of hard or calcareous skeletons $\left(\Delta \mathrm{C}_{\mathrm{CaCO}}\right)$ is 0.22 . The sum of both fractions is 1.22; therefore the percentage of regenerated inorganic carbon is equal to $(0.22 / 1+0.22) \times 100=18 \%$. Similarly, by difference, the regeneration of organic carbon, dominated by soft or organic material, is $82 \%$.

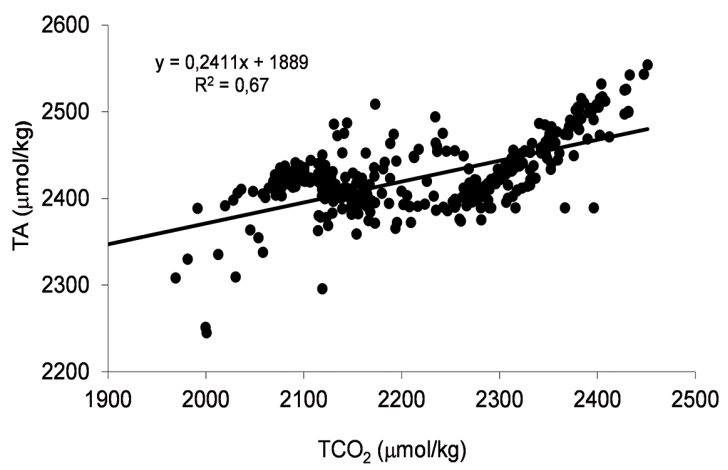

Figure 6. TA versus $\mathrm{TCO}_{2}$ at the sampling station in Cariaco Basin from January 2006 to September 2007.

These values are similar to those reported by BROECKER and PENG (1982), who obtained 1 mol $\mathrm{CaCO}_{3}$ per 4 moles $\mathrm{C}_{\text {org }}$ using a slope of $\sum \mathrm{CO}_{2}$ versus TA with surface data and Antarctic bottom water. The results in this investigation are in agreement with reports by RÍOS et al. (1995) in the northeastern Atlantic, which indicated that the regeneration of carbon in water layers between 0 and $1000 \mathrm{~m}$ and $>2300 \mathrm{~m}$ is controlled by the fraction of soft tissue in the surface layer ( $86 \%$ ), with the contribution of inorganic or hard calcareous tests being only $14 \%$.

The vertical distribution of regenerated organic carbon in the Cariaco Basin (Figure 7) shows highest variability in the photic zone, with two maxima of $81.1 \%$ and $84.1 \%$ at $1 \mathrm{~m}$ and $55 \mathrm{~m}$, respectively. The $81.1 \%$ value coincides with the maximum in primary productivity. However, the $55 \mathrm{~m}$ peak suggests mineralization of organic material. Other mechanisms that cannot be ruled out are contributions from the vertical migration of mesozooplankton and nekton such as Bregmaceros cantori which migrates between the oxic water layers to anoxic layers deeper than 500 m (MARÍN et al., 1989), as well as lateral advection that produces anomalies in the sedimentation of particulate material (TAYLOR et al., 2000). These migrations, along with the microbial production in situ, have important consequences in the anomalies of the vertical flux of carbon in the Cariaco Basin, and may enrich the carbon fluxes below $275 \mathrm{~m}$, in particular in the proximity of 455 $m$ water depth (TAYLOR et al., 2000). On the other hand, at depths between 7 and $35 \mathrm{~m}$ the values of regenerated organic carbon oscillated between approximately $44 \%$ and $64 \%$, respectively. Between $55 \mathrm{~m}$ and $250 \mathrm{~m}$ there was little variation, with values between $52 \%$ and $64 \%$. Below the anoxic threshold, located between 250 and $350 \mathrm{~m}$, a third maximum of $70-80 \%$ was detected, which is lower than those in the photic zone. Most previous studies have found the oxic/anoxic interface in the Cariaco Basin (usually defined by the appearance of sulfide) to be at between 250 $\mathrm{m}$ and $300 \mathrm{~m}$ water depth (MCPARLAND et al., 2013; SCRANTON et al., 2014). REIMERS and SUESS (1983), EMERSON (1985) and THUNELL et al. (2000) note that the degradation and preservation of organic carbon in marine ecosystems is commonly associated with the availability of dissolved oxygen, whereby decomposition under aerobic conditions is usually more efficient than under anaerobic conditions (BLAIR et al., 2012; MEHRBACH et al., 1973, KEELLER et al., 2002). This is corroborated by the proportions of regenerated organic $\mathrm{C}$ determined in the oxic and anoxic layers of the Cariaco Basin. This appears to be different from observations made in the Black Sea, where mineralization is a sink for organic matter and DOC, even under anoxic conditions, obviates any associated DOC accumulation. Some workers have also suggested that concentrations are high relative to oceanic levels because, unlike the ocean, the Black Sea receives a proportionately large amount of terrigenous DOC from rivers such as the Danube (MARGOLIN et al., 2016).

The two maxima at the surface are in agreement with the high productivity which attains values of $17 \mathrm{mgC}$ $\mathrm{m}^{-3} \mathrm{~h}^{-1}$ (Figure 2). The third peak at $300 \mathrm{~m}$ is associated with intense chemotrophic microbial activity that utilizes reduced sulfur species and methane as energy sources 


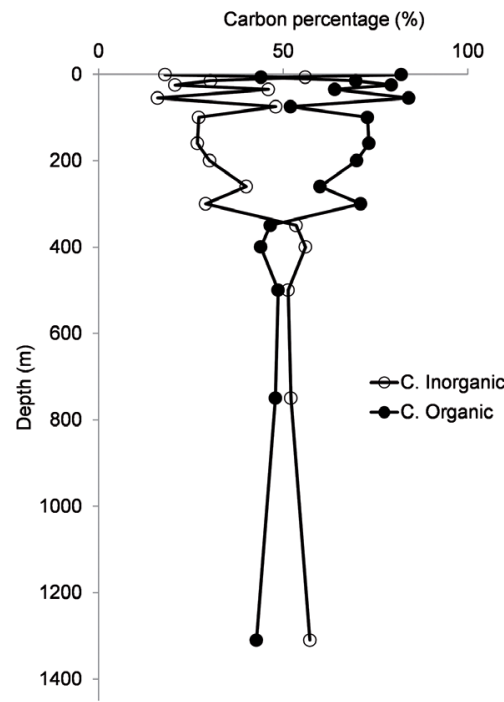

Figure 7. Vertical distribution of the regeneration of organic and inorganic carbon at the sampling station in Cariaco Basin from January 2006 to September 2007.

(TAYLOR et al., 2001). Stratified water columns, disposed to anoxia, contribute to the biological production of carbon at the redoxcline (SOROKIN, 1972; INDREBØ et al., 1979; JØRGENSEN et al., 1991; SOROKIN et al., 1995; WARDS, 2008; LORENZONI et al., 2013). Chemical gradients of electron donors and acceptors at the redox interface are ultimately sustained by the anaerobic mineralization of organic material exported from the photic zone. THUNELL et al. (2000) indicate that the proportion of carbon mineralized in the oxic layer increases in parallel with increasing primary and that decreased degradation in the anoxic zone may also arise because more labile fractions of organic carbon have already been mineralized in the upper layers. Despite this, THUNELL et al. (2000) note that sulfate reduction in the anoxic zone of Cariaco Basin can also be efficient as aerobic respiration for the mineralization of organic material. The vertical distribution of inorganic carbon (Figure 6) is inverse to that observed for organic carbon, with three minima of $19 \%, 16 \%$ and $29 \%$ located at the surface, $55 \mathrm{~m}$ and $300 \mathrm{~m}$, respectively, and two maxima of $56 \%$ and $52 \%$ located from 15 to $25 \mathrm{~m}$ and at $400 \mathrm{~m}$. An important feature is that from $300 \mathrm{~m}$ to the seafloor $(1310 \mathrm{~m})$, the variations in the regeneration of organic and inorganic carbon are close to $50 \%$, ranging from 48 to $55 \%$ for organic carbon and inorganic carbon. BROECKER and PENG (1982) observed similar results, and indicated that for deep waters the proportion of both fractions can be $50 \%$. RÍOS et al. (1995) report that in the NE Atlantic the fraction regenerated from hard calcareous skeletons increases to $51 \%$ at depths $>2300 \mathrm{~m}$ due to the increase in $\mathrm{TCO}_{2}$ and decrease in temperature. In the Cariaco Basin, despite the temperature at the surface's reaching $28^{\circ} \mathrm{C}$ and decreasing gradually from $17^{\circ} \mathrm{C}$ at $250 \mathrm{~m}$ to the seafloor (Figure 2), no increases in inorganic carbon are observed.

Primary productivity in the Cariaco Basin is high throughout the year and shows a seasonal trend with maximum values of $17 \mathrm{mgC} \mathrm{m} \mathrm{m}^{-3} \mathrm{~h}^{-1}$. Productivity is influenced by the upwelling of cold nutrient rich waters beginning in January. Dissolved $\mathrm{CO}_{2}$ increases with depth from 1968 - $2300 \mu \mathrm{mol} \mathrm{kg} \mathrm{kg}^{-1}$ at the surface to $2451 \mu \mathrm{mol} \mathrm{kg}$ ${ }^{1}$ at the sea floor due to the degradation of organic material. An influence of alkalinity was observed on the dissociation and regeneration of carbon dioxide, leading to percentages in the inorganic and organic fractions regenerated in the water column of 18 and $82 \%$, respectively. No seasonal variation in the regeneration of carbon in Cariaco Basin was observed. Consequently, regenerated carbon in the Cariaco Basin was dominated by the soft tissues of planktonic organisms. The regeneration of organic carbon below the oxic-anoxic interface partly originates from chemotrophic respiration pathways.

\section{ACKNOWLEDGEMENTS}

This study was financially supported by the Cariaco Project (Carbon Retention in a Colored Ocean; $\mathrm{N}^{\mathrm{o}}$ 2000001702), Fonacit, the Research Council of the University of Oriente, Venezuela (Project CI-5-18011079/02) and the Marine Research Station (EDIMARFLASA), Punta de Piedras, Nueva Esparta. We wish, further, to thank the captain and crew of R/V Hermano Gines (EDIMAR-FLASA, Venezuela) for their assistance during the fieldwork. This study was part of the Doctoral Thesis of Aristide Márquez of the Oceanographic Institute of Venezuela.

\section{REFERENCES}

ABRANTES, F.; CERMENO, P.; LOPES, C.; ROMERO, O.; MATOS, L.; VAN IPEREN, J.; RUFINO, M.; MAGALHÃES, V. Diatoms Si uptake capacity drives carbon export in coastal upwelling systems. Biogeosciences, v. 13, p. 4099-4109, 2016.

ALVERA-AZCÁRATE, A.; BARTH, A.; WEISBERG, R. A nested model of the Cariaco Basin (Venezuela): description of the basin's interior hydrography and interactions with the open ocean. Ocean. Dynam. v. 59, n.1, p. 97-120, 2009.

ASTOR, I. M.; MERI, J. A.; MULLER-KARGER, F. Variabilidad estacional hidrográfica en la fosa de Cariaco. Mem. Soc. Cien. Nat. La Salle, v. 68, n. 149, p. 61-72, 1998. 
ASTOR, Y. M.; LORENZONI, L.; THUNELL, R.; VARELA, R.; MULLER-KARGER, F.; TROCCOLI, L.; TAYLOR, G. T.; SCRANTON, M. I.; TAPPA, E; RUEDA-ROA, D. Interannual variability in sea surface temperature and $f \mathrm{CO}_{2}$ changes in the Cariaco Basin. Deep Sea Res. Part II Top. Stud. Oceanogr., v. 93, p. 33-43, 2013.

ASTOR, Y. M.; SCRANTON, M. I.; MULLER-KARGER, F.; BOHRERD, R.; GARCIA, J. $f \mathrm{CO}_{2}$ variability at the CARIACO tropical coastal upwelling time series station. Mar. Chem., v. 97, n. 3-4, p. 245-261, 2005.

ASTOR, Y.; MULLER-KARGER, F.; SCRANTON, M. I. Seasonal and interannual variation in the hydrographic of the Cariaco Basin: implications for basin ventilation. Cont. Shelf Res., v. 23, n. 1, p.125-144, 2003

BAUER, J. E.; WEI-JUN, C.; RAYMOND, P. A.; BIANCHI, T. S.; HOPKINSON, C. S.; REGNIE, P. A. G. The changing carbon cycle of the coastal ocean. Nature, v. 504, n. 7478, p. 61-70, 2013.

BERGER, W. H.; FISCHER, K.; LAI, C.; WU, G. Ocean carbon flux: Global maps of primary production and export production. In: AGEGIAN, C. (Ed.). Biogeochemical cycling and fluxes between the deep euphotic zone and other oceanic realms. Rockville: U.S. Dept. of Commerce, National Oceanic and Atmospheric Administration, Oceanic and Atmospheric Research, Office of Undersea Research, 1988. p. 131-176.

BLAIR, N. E.; ALLER, R. C. The fate of terrestrial organic carbon in the marine environment. Ann. Rev. Mar. Sci., v. 4, p. 401423, 2012.

BRELAND, J. A.; BYRNE, R. H. Spectrophotometric procedures for determination of sea water alkalinity using bromocresol green. Deep Sea Res. Part I: Oceanogr. Res. Pap., v. 40, n. 3, p. 629-641, 1993.

BROECKER, W.; PENG, T. H. Tracers in the sea. New York: Eldigio Press, 1982. p. 690

CAPONE, D. G.; HUTCHINS, D. A. Microbial biogeochemistry of coastal upwelling regimes in a changing ocean. Nat. Geosci., v. 6, p. 711-717, 2013.

CLAYTON, T. D.; BYRNE, R. H. Spectrophotometric seawater $\mathrm{pH}$ measurements: total hydrogen ion concentration scale calibration of $m$-cresol purple and at-sea results. Deep Sea Res. Part I: Oceanogr. Res. Pap., v. 40, n. 10, p. 2115-2129, 1993.

COBO-VIVEROS, A. M.; PADIN, X. A.; OTERO, P.; DE LA PAZ, M.; RUIZ-VILLARREAL, M.; RÍOS, A. F.; PÉREZ, F. F. Short-term variability of surface carbon dioxide and sea-air $\mathrm{CO}_{2}$ fluxes in the shelf waters of the Galician coastal upwelling system. Sci. Mar., v. 77, n. 1, p. 37-48, 2013.

DICKSON, A. G.; GOYET, C. (Eds). DOE. Handbook of methods for the analysis of the various parameters of the carbon dioxide system in sea water, v. 2. ORNL/CDIAC-74. Washington: U. S. Department of Energy, 1994. 187 p.

EMERSON, S. Organic carbon preservation in marine sediments. In: SUNQUIST, E. T.; BROECKER, W. S. (Ed.). The carbon cycle and atmospheric $\mathrm{CO}_{2}$ : Natural variations archean to present. New York: American Geophysical Union, 1985. p. $78-87$.

FEBRES-ORTEGA, G.; HERRERA, L. E. Interpretacion dinamica de algunas de las caracteristicas oceanograficas de la Fosa de Cariaco, Mar Caribe. Boletín del Instituto Oceanográfico de Venezuela, v. 14, n.1, p. 3-29, 1975.

FEBRES ORTEGA, G. Circulación de las aguas superiores de la Fosa de Cariaco en Abril de 1974. Bol. Inst. Oceanogr. Univ. Oriente, v. 13, n. 1-2, p. 79-86, 1974.
GATTUSO, J. P.; MAGNAN, A.; BILlÉ, R.; CHEUNG, W.; HOWES, E. L.; JOOS, F.; ALLEMAND, D.; BOPP, L.; COOLEY, S. R.; EAKIN, C. M.; HOEGH-GULDBERG, O.; KELLY, R. P.; PÖRTNER, H. O.; ROGERS, A.; BAXTER, J. M.; LAFFOLEY, D.; OSBORN, D.; RANKOVIC, A.; ROCHETTE, J.; SUMAILA, U. R.; TREYER, S.; TURLE, C. Contrasting futures for ocean and society from different anthropogenic $\mathrm{CO}_{2}$ emissions scenarios. Science., v. 349, n. 6243, p. aac4722, 2015.

HANSELL, D. A.; CARLSON, C. A.; REPETA, D. J.; SCHLITZER, R. Dissolved organic matter in the ocean: A controversy stimulates new insights. Oceanography, v. 22, n. 4, p. 202-211, 2009.

HERRERA, L. E. FEBRES-ORTEGA, G. Kinematics of the windgenerated velocity field in the surface waters off eastern Venezuela, Caribbean Sea. Bol. Inst. Oceanogr. Univ. Oriente, 1975, vol. 14, no 2, p. 165-186.

HUTCHINS DA, F. FU, Y. ZHANG, M.E. WARNER, Y. FENG, K. PORTUNE, P.W. BERNHARDT. \& M.R. MULHOLLAND. $\mathrm{CO} 2$ control of Trichodesmium N2 fixation, photosynthesis, growth rates, and elemental ratios: Implications for past, present, and future ocean biogeochemistry. Limnol Oceanogr. v. 52 n. 4 p. 1293-1304, 2007.

IANSON, D.; ALLENA, S. E.; HARRISA, S. L.; ORIANSA, K. J.; VARELA, D. E.; WONG, C. S. The inorganic carbon system in the coastal upwelling region west of Vancouver Island, Canada. Deep Sea Res. Part I: Oceanogr. Res. Pap. v. 50, n. 8, p. 1023-1042, 2003.

INDREBØ, G.; PENGERUD, B.; DUNSA, I. Microbial activities in a permanently stratified estuary. I. Primary production and sulfate reduction. Mar. Biol., v. 51, n. 4, p. 295-304, 1979.

JOHN, D.; WANG, Z. A.; LIU, X.; BYRNE, R. H.; CORREDOR, J.; LÓPEZ, J. M.; CABRERA, A.; BRONK, D. A.; TABITA, F. R.; PAUL, J. H. Phytoplankton carbon fixation gene (RuBisCO) transcripts and air-sea $\mathrm{CO}_{2}$ flux in the Mississippi River plume. ISME J., v. 1, n. 6, p. 517-531, 2007.

JOHNSON, R. A.; WICHERN, D. W. Applied Multivariate Statistical Analysis. $3^{\text {rd }}$ ed. New York: Prentice Hall, 1992. 156 p.

JØRGENSEN, B. B.; FOSSING, H.; WIRSEN, C. O.; JANNASCH, H. W. Sulfide oxidation in the anoxic Black Sea chemocline. Deep Sea Res. Part I: Oceanogr. Res. Pap. v. 38, Suppl. 2, p. S1083-S1103, 1991.

KEELLER, K.; SLATER, R.; BENDER, M.; KEY, R. Possible biological or physical explanations for decadal scale trends in North Pacific nutrient concentration and oxygen utilization. Deep. Sea. Res. II., v. 49, p. 325-362. 2002.

KHATIWALA, S.; TANHUA, T.; MIKALOFF FLETCHER, S.; GERBER, M.; DONEY, S. C.; GRAVEN, H. D.; GRUBER, N.; MCKINLEY, G. A.; MURATA, A.; RÍOS, A. F.; SABINE, C. L. Global ocean storage of anthropogenic carbon. Biogeosciences, v. 10, p. 2169-2179, 2013.

KNAP, A. H.; MICHAELS, A. F.; STEINBERG, D.; BAHR, F.; BATES, N.; BELL, S.; COUNTWAY, P.; CLOSE, A.; DOYLE, A.; DOW, R.L.; HOWSE, F.; GUNDERSEN, K.; JOHNSON, R.; KELLY, R.; LITTLE, R.; ORCUTT, K.; PARSONS, R.; RATHBUN, C.; SANDERSON, M.; STONE, S. BATS methods manual. Vol. 4. Woods Hole: U.S. JGOFS Planning Office, Woods Hole, 1997. 136 p.

LEWIS, E.; WALLACE, D. Program developed for $\mathrm{CO}_{2}$ system calculations. 1995. Available: $<\mathrm{http}: / /$ cdiac.ornl.gov/oceans/ $\mathrm{Co}_{2}$ rprt.html $>$. Accessed: 2016/12/12. 
LIU, K. K.; ATKINSON, L.; CHEN, C. T. A.; GAO, S.; HALL, J.; MACDONALD, R. W.; MCMANUS, L. T.; QUINONES, R. Exploring continental margin carbon fluxes in the global context. Eos, Trans. Amer. Geophys. Union., v. 81, n. 52, p. 641- 644, 2000.

LORENZONI, L.; TAYLOR, G. T.; BENITEZ-NELSON, C.; HANSELL, D. A.; MONTES, E.; MASSERINI, R.; FANNING, K.; VARELA, R.; ASTOR, Y.; GUZMÁN, L.; MULLER-KARGER, F. E. Spatial and seasonal variability of dissolved organic matter in the Cariaco Basin. J. Geophys. Res. Biogeosci., v. 118, p. 1-12, 2013.

LOUANCHI, F.; NAJJAR, R. G. A global monthly climatology of phosphate, nitrate, and silicate in the upper ocean: Springsummer export production and shallow remineralization. Global Biogeochem. Cycles, v. 14, n. 3, p. 957-977, 2000.

MADRID, VANESSA, M., et al. Phylogenetic diversity of bacterial and archaeal communities in the anoxic zone of the Cariaco Basin. Applied and environmental microbiology, v. 67, n. 4, p. 1663-1674, 2001.

MARGOLIN, A.; GERRINGA, L. J. A.; HANSELL, D. A.; RIJKENBERG, M. J. A. Net removal of dissolved organic carbon in the anoxic waters of the Black Sea. Mar. Chem., v. 183, p. 13-24, 2016.

MARÍN, B.; GÓMEZ, A.; UROSA, L. Taxonomía y distribución del Ictioplancton en la fosa de Cariaco, Venezuela. Bol. Inst. Oceanogr. Venezuela, v. 28, n. 1-2, p. 15-27. 1989.

MCKINLEY, G. A.; PILCHER, D. J.; FAY, A. R.; LINDSAY, K.; LONG, M. C.; LOVENDUSKI, N. S. Timescales for detection of trends in the ocean carbon sink. Nature, v. 530, p. 469-472, 2016.

MCPARLAND, E., BENITEZ-NELSON, C., TAYLOR, G., THUNELL. G., ROLLINS, A., LORENZONI, L. Cycling of suspended particulate phosphorus in the redoxcline of the Cariaco Basin. Mar. Chem., 2015, v. 176, p. 64-74, 2013

MEHRBACH, C.; CURBERSON, C.; HAWLEY, J.; PYTKOWICZ, T. Measurement of the apparent dissociation constants of carbonic acid in seawater at atmospheric pressure. Limnol. Oceanogr., v. 18, p. 897-907, 1973.

MILLERO, F. Thermodynamics of the carbon dioxide system in the oceans. Geochim Cosmochim Acta, v. 59, n. 4, p. 661-677, 1995.

MULLER-KARGER, F. E; APARICIO, R. Mesoscale Processes Affecting Phytoplankton Abundance in the Southern Caribbean Sea. Cont. Shelf Res., v. 14, n. 2-3, p. 199-221, 1994.

MULLER-KARGER， F.; VALERA， R.; THUNNEL， R.; SCRANTON, M.; BOHRER, R.; TAYLOR, G.; CAPELO, J.; ASTOR, I.; TAPPA, E.; HO, T.; IABICHELLA, M.; WALSH, J. Annual cycle of primary production in the Cariaco Basin: Response to upwelling and implications for vertical export. $J$. Geophys. Res., v. 106, n. 3, 4527-4542, 2001.

OCCC. 2004. Ocean carbon climate change. Scott. C. Doney editor. USA. $108 \mathrm{pp}$.

PACE, M.; KNAUER, G. A.; KARL, D. M.; MARTIN, J. H. Primary production, new production and vertical flux in the eastern Pacific Ocean. Nature, v. 325, p. 803-804, 1987.

PACKARD, T. T.; OSMA, N.; FERNÁNDEZ-URRUZOLA, I.; CODISPOTI, L. A.; CHRISTENSEN, J. P.; GÓMEZ, M. Peruvian upwelling plankton respiration: calculations of carbon flux, nutrient retention efficiency, and heterotrophic energy production. Biogeosciences, v. 12, n. 9, p. 2641-2654, 2015 .
REDFIELD, A.C., KETCHUM, B.H., RICHARDS, F.A. The influence of organisms on the composition of seawater. In: Hill, M.N. Ed.., The Sea, v. 2, p. 26-77, 1963.

REIMERS, C.; SUESS, E. The partitioning of organic carbon fluxes and sedimentary organic matter decomposition rates in the ocean. Mar. Chem., v. 13, n. 2, p. 141-168, 1983.

RICHARDS, F. Some chemical and hydrographic observations along the north coast of South America - I. Cabo Tres Puntas to Curacao, including the Cariaco Trench and the Gulf of Cariaco. Deep Sea Res, 1960, v. 7, n. 3, p. 163-182, 1960.

RÍOS, A. F.; ANDERSON, T. R.; PÉREZ, F. F. The carbonic system distribution and fluxes in the NE Atlantic during spring 1991. Progr. Oceanogr., v. 35, n. 4, p. 295-314, 1995.

RÍOS, A. F.; FRAGA, F.; PÉREZ, F. F. Estimation of coefficients for the calculation of "NO", "PO" and "CO", starting from the elemental composition of natural phytoplankton. Sci. Mar., v. 53 , n. 4, p. 779-784, 1989.

ROMERO, O. E.; THUNELL, R. C.; ASTOR, Y.; VARELA, R. Seasonal and interannual dynamics in diatom production in the Cariaco Basin, Venezuela. Deep Sea Res. Part I: Oceanogr. Res. Pap., v. 56, n. 4, p. 571-581, 2009.

REUER, M.; BOYLE, K., EDWARD A.; COLE, JULIA, E. A midtwentieth century reduction in tropical upwelling inferred from coralline trace element proxies. Earth Planet SC Lett, v. 210, n. 3, p. 437-452, 2003.

RUEDA-ROA， D.; MULLER-KARGER， F. The southern Caribbean upwelling system: Sea surface temperature, wind forcing and chlorophyll concentration patterns. Deep. Sea. Res.I. v. 78, p. 102-114, 2014

SCRANTON, M., et al. Controls on temporal variability of the geochemistry of the deep Cariaco Basin. Deep Sea Res.I: Oceanogr. Res. Papers, 2001, v. 48, n.7, p. 1605-1625, 2002

SCRANTON, M. I.; TAYLOR, G. T.; THUNELL, R. C.; BENITEZ-NELSON， C. R.; MULLER-KARGER, F.; FANNING, K.; LORENZONI, L.; MONTES, E.; VARELA, R.; ASTOR, Y. Interannual and subdecadal variability in the nutrient geochemistry of the Cariaco Basin. Oceanography, v. 27, n. 1, p. 148-159, 2014.

SIPPO, J. Z.; MAHER, D. T.; TAIT, D. R.; HOLLOWAY, C.; SANTOS, I. R. Are mangroves drivers or buffers of coastal acidification? Insights from alkalinity and dissolved inorganic carbon export estimates across a latitudinal transect. Global Biogeochem. Cycles, v. 30, n. 5, p. 753-766, 2016

SITCH, S.; FRIEDLINGSTEIN, P.; GRUBER, N.; JONES, S. D.; MURRAY-TORTAROLO, G.; AHLSTRÖM, A.; LEVIS, S.; LEVY P. E.; LOMAS M.; POULTER B.; VIOVY N.; ZAEHLE S.; ZENG N.; ARNETH A.; BONAN G.; BOPP L.; CANADELL J. G.; CHEVALLIER F.; CIAIS P.; ELLIS R.; GLOOR M.; PEYLIN P.; PIAO S. L.; LE QUÉRÉ C.; SMITH B.; ZHU Z.; MYNENI R. Recent trends and drivers of regional sources and sinks of carbon dioxide. Biogeosciences, v. 12, n. 3, p. 653-679, 2015.

SMITH, S. Phosphorus versus nitrogen limitation in the marine enviroment. Limnol. Oceanogr. v. 29, n.6, p 1149-1160,1994.

SMOAK, J. M.; BENÍTEZ-NELSON, C.; MOORE, W. S.; THUNELL, R.; ASTOR, Y.; MULLER-KARGER, F. Radionuclide fluxes and particle scavenging in Cariaco Basin. Cont. Shelf Res., v. 24, n. 13-14, p. 1451-1463, 2004.

SOKAL ROBERT, R.; JAMES, ROHLF F. Biometry. The principles and practice of statistics in biological research. 1969. 
SOROKIN, Y. I. The bacterial population and the process of hydrogen sulphide oxidation in the Black Sea. J. Cons. Perm. Inter. Explor. Mer., v. 34, p. 423-455, 1972.

SOROKIN, Y. I.; SOROKIN, P. Y.; AVDEEV, V. A.; SOROKIN, D. Y.; ILCHENKO, S. V. Biomass, production and activity of bacteria in the Black Sea, with special reference to chemosynthesis and the sulfur cycle. Hydrobiology, v. 308, n. 1, p. 61-76, 1995.

STEEMAN-NIELSEN, E. The use of radioactive carbon $\left({ }^{14} \mathrm{C}\right)$ for measuring organic production in the sea. J. Cons. Perm. Int. Explor. Mer, v. 18, n. 2, p. 117-140, 1952.

STEINBERG, D. K.; CARLSON, C. A.; BATES, N. R.; JOHNSON, R. J.; MICHAELS, A. F.; KNAP, A. H. Overview of the US JGOFS Bermuda Atlantic Time series Study (BATS): a decade-scale look at ocean biology and biogeochemistry. Deep Sea Res. Part II: Top. Stud. Oceanogr., v. 48, n. 8-9, p. 1405-1447, 2001

TAYLOR, G. T.; IABICHELLA, M.; HO, T. Y., SCRANTON, M. I.; TUNNEL, R. C.; MULLER-KARGER, F.; VARELA, R. Chemoautrotophy in the redox transition zone of the Cariaco Basin: A significant midwater source of organic carbon production. Limnol. Oceanogr., v. 46, n. 1, p. 148-163, 2001.
THUNELL, R. C.; BENITEZ-NELSON，C.; VARELA，R.; ASTOR, Y.; MULLER-KARGER, F. E. Particulate organic carbon fluxes along upwelling-dominated continental margins: Rates and mechanisms. Global Biogeochem. Cycles, v. 21, n. 1, p. 1-12, 2007.

THUNELL, R. C.; VARELA, R.; LLANO, M.; COLLISTER, J., MULLER-KARGER, F.; BOHRER, R. Organic carbon flux in an anoxic water column: sediment trap results from the Cariaco Basin. Limnol. Oceanogr., v. 45, n. 2, p. 300-308, 2000.

UNESCO/Intergovernmental Oceanographic Commission. Protocols for the Joint Global Ocean flux Study (JGOFS). Core measurements. Manual and Guides, v. 29. Paris: UNESCO, 1994. p. 128-134.

WARD, B. B. Nitrification in marine systems. In: CAPONE, D. G.; BRONK, D. A.; MULHOLLAND, M. R.; CARPENTER, E. J. Nitrogen in the marine environment. Burlington: Academy Press, 2008, p. 199-261. 